\title{
Development of Problem-Oriented Mathematics Learning Videos on Scale Material for the Fifth-Grade Elementary School Students
}

\author{
Ni Kadek Arum Padmawati ${ }^{1 *}$, Gusti Ngurah Sastra Agustika ${ }^{1}$ \\ ${ }^{1}$ Universitas Pendidikan Ganesha, Indonesia \\ "Corresponding author.Email: nikadekarumpadmawati28@undiksha.ac.id
}

\begin{abstract}
This research was conducted based on an analysis of the needs and problems that occur in the learning process. The occurrence of the Covid-19 pandemic made learning less than optimal so that students had difficulty in understanding the teaching materials. To optimize mathematics learning, it is necessary to develop learning media according to the needs of students. This research aimed to produce problem-oriented mathematics learning videos on scale material for the fifth-grade students at Public Elementary School No. 2 Ketewel, and to find out its validity. The type of research is a development research using the ADDIE model (Analyze, Design, Development, Implementation, Evaluation). The subjects of this study were subject content experts, instructional design experts, instructional media experts, and three fifth-grade elementary school students. The data collection instrument used was a questionnaire. The research data were collected using the method of observation, interviews and questionnaires. Data were analyzed using quantitative descriptive analysis and qualitative descriptive analysis. The results of this study indicated the process of developing problem-oriented mathematics learning videos on scale material for the fifth-grade elementary school students through the analysis, design, development, and evaluation stages. The results of the validity test of the instructional videos by instructional design experts obtained a percentage score of $85.41 \%$ with good qualifications. The results of the validity test of the instructional videos by instructional media experts obtained a percentage score of $85 \%$ with good qualifications. The results of the validity test of the instructional videos by subject content experts obtained a percentage score of $87.5 \%$ with good qualifications. The results of the validity test of the instructional video by individual trial subjects obtained a percentage score of $95.66 \%$ with very good qualifications. Therefore, the problem-oriented mathematics learning on scale material for the fifth-grade elementary school students is valid for use in the learning process.
\end{abstract}

Keywords: Development, Instructional Videos, Mathematics, Contextual Problems

\section{INTRODUCTION}

The expected learning conditions and environments in the 21 st century is a learning process in which there are HOT (high order thinking) activities. Learning that is accompanied by HOT activities such as problem solving is able to improve students' critical and creative thinking skills [1]. However, the covid-19 pandemic has caused learning to be suboptimal, including in training students' critical thinking skills. To optimize learning, it is important to have learning media that are suitable for the needs of students. The use of learning media is able to influence the conditions and learning environment [2].
The challenges of the times require humans to be able to develop abilities that are relevant to the needs of life such as the ability to work together, think critically, analytically, creatively and innovatively. The integration of all these abilities can be in the form of expertise in solving problems, especially life problems. The importance of education is reflected in the vision of national education, namely the realization of the education system as a strong and authoritative social institution to empower all Indonesian citizens to develop into qualified human beings so that they are able and proactive in responding to the challenges of the everchanging times [3]. 
Problem-solving abilities can be developed from an early age through learning mathematics. Mathematics is a scientific discipline that deals with numbers and calculation activities so that it can have an impact on students' thinking abilities [4]. Mathematics is used as a means to develop scientific thinking skills which is one of the vital needs to survive in the pace of life [5]. Mathematics is used as the basis for mastery of science and technology [6]. In line with that, mathematics as an abstract symbolic system requires reasoning and critical thinking in imagining mathematical theories and concepts through the power of imagination which will have an impact on their understanding of mathematical material [7].

Based on the results of Pisa 2018, the mathematics ability of students in Indonesia is still low when compared to the OECD average, around $28 \%$ of students in Indonesia reached level 2 or higher in mathematics (OECD average is 76\%). Meanwhile, only $1 \%$ of students in Indonesia could reach level 5 or higher in mathematics (OECD average of $11 \%$ ) compared to China which reached $44 \%$. Achieving levels 5-6 requires the ability to model complex situations, select, compare, evaluate, and problem-solving strategies [8].

Problem solving is an effort to solve problems by using certain procedures that require reasoning and critical thinking to be able to find solutions [9]. Problemsolving questions are not the types of questions that are solved by regular / routine procedures but rather by a challenging process [10]. Learning with problem-solving activities such as illustrating mathematical objects and their realization can help improve students' understanding of mathematical concepts and theories [5]. There are four stages of problem solving, namely (1) understanding the problem, (2) planning, (3) implementing the plan, and (4) looking back [11]. However, problem solving activities are prone to make students confused and less motivated. Therefore, learning media are needed to support the effectiveness of mathematics learning.

Mathematical principles or concepts should be presented in concrete form, which can be done by visualizing objects in mathematics learning with the help of learning media [12]. Mathematics learning is learning about science related to certain symbols that requires methods, techniques, approaches, strategies, or media in the learning process so that students are able to understand mathematics and apply it to everyday life or at a higher level [13]. The use of learning media is very important in helping students understand mathematical concepts [14].

Learning media is anything that can transmit messages or information so that it can stimulate students' thoughts, feelings, interests and attention [12]. Learning media is defined as a channel for delivering educational messages [15]. Learning media is a tool that helps teachers deliver teaching material so that it encourages students to pay attention to this material [16]. The use of learning media is able to influence the conditions and learning environment [2]. The more effective the learning media is, the more conducive the learning environment is. Good learning media are media that are in accordance with the characteristics of students. The characteristics of elementary school students are still happy to play, like to move, like to imitate, like to feel and do things directly, and enjoy working in groups [17]. It can be concluded that learning media are all forms of intermediaries that help or facilitate teachers in conveying information and learning messages effectively while influencing the conditions of the learning environment that stimulate the thoughts, feelings, interests, and attention of students.

The use of technology in making learning media can help facilitate the visualization of abstract mathematical theories so that learning will be more easily conveyed to students. This visualization can be provided through instructional videos. The Latin term for video is vidi or visum which means seeing, having visual abilities or vision [18]. Video is an audio-visual type of learning media that involves the senses of sight and hearing [19]. Learning videos are able to convey information, show processes, explain complex concepts, teach skills, set the pace of time, and encourage the emergence of certain attitudes [20]. Learning videos are able to bring real situations into the classroom through visual real pictures so that learning becomes livelier and more interactive because it can motivate student curiosity [21].

One approach to make it easier for students to develop problem-solving skills is the contextual approach. The contextual approach is an approach that shows the natural conditions of knowledge through the presentation of concepts. The concept presented links the teaching material with the context in which the material is used so that the learning experience is more relevant and meaningful in building student knowledge. At a higher level, students are able to apply their knowledge to solve complex real-world problems [22]. Learning becomes meaningful when it is associated with real-world situations by presenting in contextual situations [23]. The contextual approach sees the need for flexible transfer of knowledge through one problem into another [24]. Mathematics learning should begin with the introduction of contextual problems that are appropriate to the real situation of students [25]. Research shows that a contextual approach can improve students' critical thinking skills [26].

Contextual problems are problems that use situations experienced directly by students in real life or situations that occur in the surrounding environment [27]. Contextual problems are problems that contain real experience situations for students related to their daily lives [28]. Contextual problems are problems that contain 
context about real objects or abstract objects such as facts, concepts, or mathematical principles [29].

Thus, the introduction of problems based on a contextual approach can make it easier for students to understand problems and increase student motivation to solve them. Research scientifically showed that the use of a contextual approach in the learning process is able to improve understanding and learning outcomes of the fifth-grade students of Public Elementary School No. 13 Pangkalpinang in mathematics in the subject matter of comparison and scale [30]. Therefore, this contextual approach can be applied in learning scale concepts. Scale is a concept related to comparison and measurement. Scale is knowledge that is very useful in everyday life, such as in making maps, plans for house locations, and for making building models [31]. Scale learning that is oriented to contextual problems is expected to help develop students' ability to reason, think critically and creatively. Problem-oriented scale learning is easier to understand if it is assisted by instructional videos, because studying scale concepts requires imagination and creativity when linked in everyday life.

In line with the various research results above, based on the results of interviews with the fifth-grade teachers at Public Elementary School No. 2 Ketewel, mathematics is still a difficult subject for most students. Teachers also have difficulty explaining mathematics material to students, especially abstract theories. The combination of abstract mathematics and the Covid-19 pandemic situation has made teaching mathematics to be repeated multiple times to be understood by the students. One of the contributing factors is the students' lack of training in problem solving skills. Optimizing learning and practicing problem-solving skills requires assistance from learning media. Teachers still use instructional videos that are not structured and systematic so that their feasibility is not yet known. The learning videos used do not contain the delivery of concepts from the material discussed and have not made students practice their problem-solving skills. Making instructional videos requires analysis of various components so that it can be said to be feasible as a learning medium. One of the components that need to be considered in making instructional videos is the clarity of the storyboards used, with the aim that the learning videos can be more effective, efficient and systematic. Teachers have limited time to develop feasibility learning videos. This is due to the large number of academic and non-academic tasks that the teacher must complete, such as taking care of administrative matters which take up a lot of teacher time.

Based on the results of the problem analysis and learning needs, it is necessary to develop media in the form of problem-oriented mathematics learning videos on scale material for the fifth-grade students at Public Elementary School No. 2 Ketewel. Through this media it is expected to increase student motivation through the introduction of meaningful and contextual problems so that it is hoped to have an impact on students' problemsolving abilities.

\section{METHODS}

The type of this research is research and development (R\&D). The development model used was the ADDIE model (Analyze, Design, Development, Implementation, Evaluation) as a guide in producing products and testing their validity. Based on the selected design research model, the research procedures used in research and development consisted of Analysis, Design, Development, Implementation, and Evaluation stages.

The first stage is the analysis stage that was carried out to determine the needs and problems that exist in Public Elementary School No. 2 Ketewel. The next stage is the design stage that was carried out to clarify and facilitate video development. The development stage was carried out by developing instructional videos and conducting product trials that were consisted of subject content expert tests, learning design expert tests, learning media expert tests, and individual trials. The implementation stage was carried out by applying the product in the learning process. However, the small group trial and field trials were not carried out due to limitations caused by the Covid-19 pandemic. The evaluation stage was carried out to measure and assess the learning videos that have been applied at each stage to improve or improve the results of the products developed.

The research was conducted at Public Elementary School No. 2 Ketewel with the trial subjects consisting of subject content experts, learning design experts, instructional media experts, and three fifth-grade elementary school students. The instrument used to collect data was a questionnaire. The data collection method used was the non-test method which includes observation, interviews, and questionnaires. The data obtained were in the form of quantitative data and qualitative data so that the data analysis techniques used were quantitative descriptive analysis techniques and qualitative descriptive analysis techniques. The quantitative descriptive analysis method is a way of processing or analyzing data by systematically compiling in the form of numbers and or percentages regarding an object under study, so that a general conclusion can be obtained [32].

The score data obtained from experts in this study were analyzed using a Likert scale consisting of 4 categories as shown in the following table. 
Table 1. Category of Likert Scale Assessment with a Scale of 4

\begin{tabular}{|c|c|c|c|}
\hline \multirow{2}{*}{ No } & \multicolumn{2}{|c|}{ Score Statement } & \multirow{2}{*}{ Statement } \\
\cline { 2 - 3 } & Positive & Negative & Strongly Agree / SA \\
\hline 1 & 4 & 1 & Agree / S \\
\hline 2 & 3 & 2 & Disagree / D \\
\hline 3 & 2 & 3 & Strongly Disagree / SD \\
\hline 4 & 1 & 4 & \\
\hline
\end{tabular}

(Source: [31])

The data were analyzed using the following formula:

$P=\frac{\left.\sum \text { (answer } x \text { weight of choice }\right)}{n \times \text { highest weight }} \times 100 \%$

Furthermore, to calculate the percentage of the entire subject, the following formula was used.

Percentage $=(\mathrm{F}: \mathrm{N}) \times 100 \%$

The criteria for decision making used a conversion scale of five achievement levels.

Table 2. Conversion of Level Achievement

\begin{tabular}{|l|l|l|}
\hline Level (\%) & Qualification & \multicolumn{1}{c|}{ Description } \\
\hline $90-100 \%$ & Very Good & No need to revise \\
\hline $75-89 \%$ & Good & Slightly revised \\
\hline $65-74 \%$ & Sufficient & Revised sufficiently \\
\hline $55-64 \%$ & Lacking & Many things revised \\
\hline $0-54 \%$ & Very Lacking & Product was recreated \\
\hline
\end{tabular}

Qualitative descriptive analysis is used to interpret the data in the form of qualification criteria such as very good, good, sufficient, lacking, very lacking.

\section{RESULTS AND DISCUSSION}

The results of the research on the development of problem-oriented mathematics learning videos described the design and development of media development and the results of the validity of the development of instructional videos.

The design and development of problem-oriented mathematics learning video development was guided by the ADDIE model (Analyze, Design, Development, Implementation, Evaluation). The first stage was the analysis stage. At this stage, an analysis of needs and problems was carried out which includes analysis of student characteristics, analysis of content and facilities, analysis of basic competencies. Student characteristics were analyzed to determine the condition of the fifthgrade students at Public Elementary School No. 2 Ketewel. Based on the results of interviews with teachers at Public Elementary School No. 2 Ketewel, students at Public Elementary School No. 2 Ketewel tended to have difficulty in understanding mathematics because of its abstract nature so that it is difficult to imagine. The combination of abstract mathematics with the Covid-19 pandemic situation made teaching mathematics to be repeated multiple times so that it could be understood by students. This statement is in line with Piaget's cognitive theory which stated that elementary school children aged 7-11 years are still in concrete operational thinking. Research showed students would not be able to solve abstract problems, unless they can present them in a real or visual way [34]. One of the learning media that can present reality through visualization is learning videos. Based on these needs and problems, an audio-visual media that is able to provide visualization as well as verbalization is needed so that students can be more interested and easier to learn mathematics. Furthermore, an analysis of the selected material was carried out based on the characteristics of the students. The product developed was a problem-oriented mathematics learning video on the fifth-grade material so that the selected material was limited to the fifth-grade elementary school material. After deciding to choose the scale material, then an analysis of the competencies that must be mastered by students was carried out after using the developed product. The competency analysis carried out was an analysis of basic competencies (KD) and learning indicators on scale material for the fifth-grade elementary school students.

The second stage is design. At this stage the concept began to be designed with attention to the needs and problems that have been analyzed. At this design stage, attention was also given to the learning approach that was used as the basis for designing the instructional video. The learning approach used was a contextual approach oriented to contextual problems. At this stage, identification of the software that would be used to make the learning videos was conducted. The software used were Wondershare Filmora, PowerPoint, and Adobe Animate. Next was to make a flowchart of the learning video which includes the opening (material title, learning objectives, perception) material, practice questions, evaluation and closing. After making a flowchart, the next step was to proceed with making a storyboard to clarify the production process. The storyboard contained a collection of pictures accompanied by a description of the sound elements that would be edited into a complete learning video. In addition, at this stage a learning implementation plan (RPP) was also drawn up, and instruments for product validation were also made. The learning videos were designed to be as attractive as possible so that the problems can be conveyed in an attractive manner. Problem solving is done by referring to the theory of patterns, namely (1) understanding the problem, (2) planning, (3) implementing, and (4) checking the truth. Contextual problems are presented through mission-completing games designed to be played independently or in groups. However, it is recommended to be played in groups so that learning becomes more fun and collaborative. Problems are also presented in order from easiest to most difficult. The learning videos contain pictures that support the scale material so that students can observe the images and more easily understand the scale material. 
The third stage is the development stage. At this point, the learning video was developed in a systematic step-by-step way, which includes recording pictures, recording sound, editing pictures and sound (video editing), exporting the video and inserting it on a CD-R. Some of the scenes in the video were created using the PowerPoint application and some were created using the Adobe Animate and Wondershare Filmora application. The final editing process was carried out using filmora software including the audio editing. In addition, at this stage a CD-R cover design was also made as well as the product usage instructions and the learning implementation plans (RPPs), afterward validity tests through product trials were carried out. The validity test of problem-oriented learning videos was assessed by subject content experts, instructional design experts, instructional media experts and also assessed by students during individual trials. The instrument used was a questionnaire. The results of the assessment were followed up in the form of media improvements if necessary.

The fourth stage is implementation. At this stage, the learning videos that have been produced were then tested in the learning process to determine the effectiveness of the instructional videos that have been given. Before the video was implemented, experts validated the product, including subject content experts, instructional media experts, and instructional design experts by filling out the questionnaire given. However, the small group trial and field trials could not be carried out due to limitations caused by the Covid-19 pandemic.

The fifth stage is the evaluation. At this stage, an evaluation was carried out to assess the learning videos that have been applied at each stage in order to improve the results of the products developed. The assessment carried out only includes validation of subject content experts, learning design experts, learning media experts, and individual trials due to limitations that were caused by the Covid-19 pandemic.

The validity of this problem-oriented mathematics learning video was measured from the results of the assessment of subject content experts, learning design experts, instructional media experts and individual trials. The instrument used to determine the validity of the instructional video was a questionnaire. The problemoriented mathematics learning video that has been developed was first tested for its feasibility by three experts, namely subject content experts, instructional design experts, and instructional media experts. After being declared feasible by the three experts, the validity test of the learning video was continued with an assessment of individual trials. The validity test results obtained can be seen in the following table.
Table 3. Validity Results of the Learning Video Development

\begin{tabular}{|c|l|c|c|}
\hline No & Subject Trial & $\begin{array}{c}\text { Results } \\
\text { Validity }(\%)\end{array}$ & $\begin{array}{c}\text { Qualification } \\
\text { Percentage }\end{array}$ \\
\hline 1 & $\begin{array}{l}\text { Learning Design } \\
\text { Expert Test }\end{array}$ & 85.41 & Good \\
\hline 2 & $\begin{array}{l}\text { Learning Media } \\
\text { Expert Test }\end{array}$ & 85 & Good \\
\hline 3 & $\begin{array}{l}\text { Subject Content } \\
\text { Expert Test }\end{array}$ & 87.5 & Good \\
\hline 4 & Individual Trials & 95.66 & Very Good \\
\hline
\end{tabular}

Based on the acquisition of the validity test, it can be concluded that the problem-oriented mathematics learning video on scale material for the fifth-grade elementary school students was valid so that it is suitable to be used in the learning process. In line with the acquisition of the validity test, the trial subjects also gave several comments and suggestions in response to the product being tested and for product improvement.

Table 4. Suggestions and Comments from Experts

\begin{tabular}{|l|l|l|}
\hline Validators & $\begin{array}{c}\text { Suggestions and } \\
\text { Comments }\end{array}$ & \multicolumn{1}{|c|}{ Revision } \\
\hline $\begin{array}{l}\text { Subject } \\
\text { Content } \\
\text { Expert }\end{array}$ & $\begin{array}{l}\text { Operations should } \\
\text { not be operated as } \\
2 \mathrm{~m} \times 3 \mathrm{~m} \text { but as } \\
(2 \times 3) \text { unit area. }\end{array}$ & $\begin{array}{l}\text { Removing the } \\
\text { unit on } \\
\text { arithmetic } \\
\text { operations }\end{array}$ \\
\hline $\begin{array}{l}\text { Learning } \\
\text { Media } \\
\text { Expert }\end{array}$ & $\begin{array}{l}\text { Storyboard should } \\
\text { be improved. } \\
\text { Dubbing should be } \\
\text { completed }\end{array}$ & $\begin{array}{l}\text { Fixing the } \\
\text { storyboard by } \\
\text { filling in the } \\
\text { video and audio } \\
\text { column }\end{array}$ \\
\cline { 3 - 3 } & & $\begin{array}{l}\text { Finishing the } \\
\text { dubbing part }\end{array}$ \\
\hline
\end{tabular}

Table 5. Comments on Product Development in Individual Trial

\begin{tabular}{|l|l|c|}
\hline No. & \multicolumn{1}{|c|}{ Comments and Suggestions } & Revision \\
\hline 1. & $\begin{array}{l}\text { I am very motivated to learn math } \\
\text { using video lessons and I can } \\
\text { know the scale well. }\end{array}$ & - \\
\hline 2. & $\begin{array}{l}\text { I am very happy watching this } \\
\text { math lesson video, I understand } \\
\text { more about scale learning }\end{array}$ & - \\
\hline 3. & $\begin{array}{l}\text { I am very excited to learn about } \\
\text { map scale, and I can see clearly } \\
\text { the video. }\end{array}$ & - \\
\hline
\end{tabular}

The final result of developing this problem-oriented mathematics learning video can be seen in Figure 1 and Figure 2 below. 


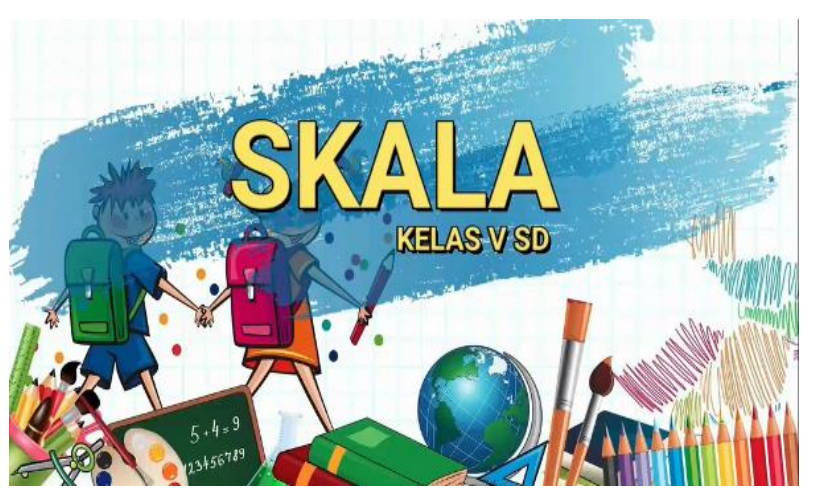

Figure 1. Initial Display of Learning Videos
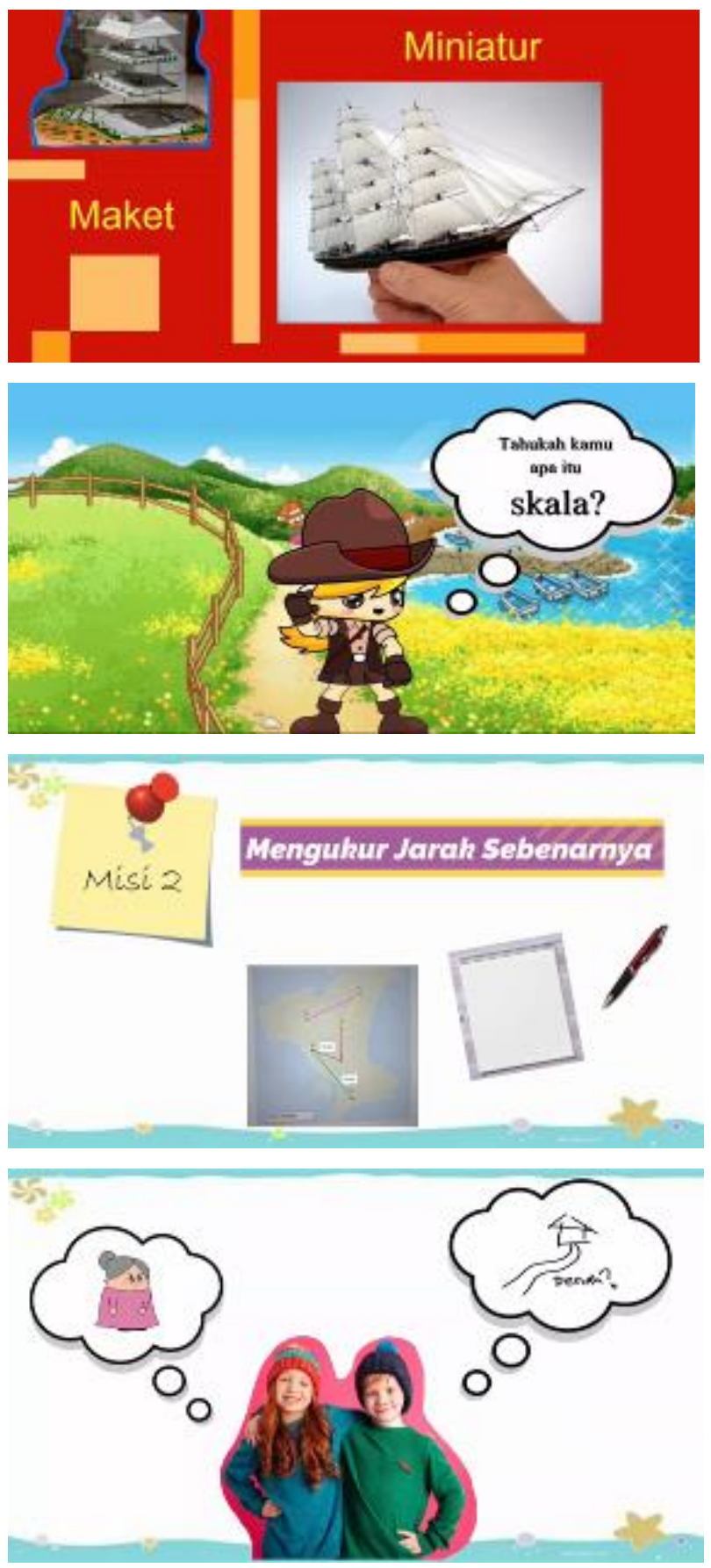

Figure 2. Video Content Display
This development research resulted in a product in the form of a problem-oriented mathematics learning video on scale material for the fifth-grade students at Public Elementary School No. 2 Ketewel. This media was developed to facilitate students in understanding the scale material in more depth by providing contextual problems. Even though students are presented with contextual problems, learning can still be fun because problem presentation is also conveyed through mission completion games. The presentation of problems through games makes the problems no longer feared by students. This statement is supported by comments and suggestions given by students in the individual trial assessment questionnaire. The three respondents said that through problem-oriented mathematics learning videos on scale material for the fifth-grade elementary school students, it could make them understand the scale better and it was more fun. In addition, the presentation of contextual problems also begins with easy problems leading to more difficult level problems so that students can be led to be able to solve the problems given. Problem solving is done by referring to the theory of patterns, namely (1) understanding the problem, (2) planning, (3) implementing, and (4) checking the truth. In problem solving efforts, students are designed to collaborate and discuss with their group friends so that learning becomes more collaborative and fun. [35] suggested that the application of group work methods in solving joint problems can make learning more effective. The media is also accompanied by supporting pictures that are relevant to the material so that it can make it easier for students to understand the scale material.

In line with the quality of the product produced, the validity test results showed that the problem-oriented mathematics learning video is valid so that it is suitable for use in the learning process. These results are also due to the development of instructional videos using the ADDIE model which consists of the analysis, design, development, implementation and evaluation stages. However, the implementation stage was not carried out due to limitations caused by the Covid-19 pandemic. This is supported by the statement that the ADDIE model has a systematic nature and is based on the theoretical foundation of learning design so that it can solve learning problems according to the needs and characteristics of students [36].

Based on the results of the expert's assessment of the subject content of the learning material components, the score ranges from 3 (good) and 4 (very good). Assessment criteria on aspects of learning materials include: (a) curriculum, (b) material, and (b) grammar. The quality of the learning material aspects received a good score with a percentage of $87.5 \%$ from the subject content experts. Each material has its own characteristics so that it can be used as a consideration in the presentation and selection of the material. [37] argued that in essence mathematics is a science that deals with 
structures, relationships and abstract concepts that are developed logically. Even though mathematics is the science of abstract concepts, its teaching can also be done by manipulating concrete objects through analogy techniques or by providing illustrations from the real-life context of students or the surrounding environment. [5] also argued that mathematics is a science that is used as a means of developing scientific thinking skills which is essentially one of the vital needs to be able to survive in the pace of social life. Therefore, studying mathematics is not only about learning knowledge but also being able to provide certain skills. Thus, based on the results of the assessment of the subject content experts, it can be decided that the problem-oriented learning video is valid and feasible to be given to students and used in the learning process, especially in mathematics on scale material for the fifth-grade elementary school students.

Based on the results of the assessment of problemoriented mathematics learning videos from instructional design experts on the learning design components, the final score ranges from a score of 3 (good) and a score of 4 (very good). Learning design assessment criteria include: (a) objectives, (b) strategies, and (c) evaluation. The quality of the learning design received a good score with a percentage of $85.41 \%$ from the instructional design experts. Good learning design greatly affects learning outcomes. According to [38] if the learning design is poorly designed or used, the learning process and results will also be less good, inefficient, and less motivating. Therefore, it is necessary to have linkages between components in learning planning. [39] suggested that in the preparation of a learning implementation plan, there is a need for a link between $\mathrm{KI}$ and $\mathrm{KD}$, learning materials, learning activities, assessments, and learning resources. Thus, based on the results of the assessment of the learning design, it can be decided that the problem-oriented learning video is valid and feasible to be given to students and used in the learning process, especially in mathematics on scale material for the fifth-grade elementary school students.

Based on the results of the assessment of the problemoriented mathematics learning video from the results of the assessment of instructional media experts on the learning media components, the score ranges from a score of 3 (good) and a score of 4 (very good). Learning media assessment criteria include: (a) technical, and (b) display. The quality of learning media received a good score with a percentage of $85 \%$ from the instructional media experts. The use of instructional videos has an important role in optimizing the learning process and outcomes. Learning videos can help visualize mathematical theories, facts, and concepts to become more realistic. [40] suggested that instructional videos are media capable of conveying messages and information through a combination of sound and image elements. Learning videos are classified as audio-visual media because of their ability to show objects, places and events through a moving image format accompanied by audio. Thus, based on the results of the assessment of instructional media experts, it can be decided that the problem-oriented learning video is valid and feasible to be given to students and used in the learning process, in mathematics on scale material for the fifth-grade elementary school students.

Based on the results of the assessment of problemoriented mathematics learning videos from students on individual trials of the learning media components, the score ranges from a score of 2 (good) and a score of 1 (very good). The criteria for assessing learning media include: (a) appearance, (b) material, (c) motivation, and (d) use. The quality of the instructional videos received a very good score with a percentage of $95.66 \%$ of the results of individual trials. This percentage is also supported by comments given by students on problemoriented mathematics learning videos, which received a positive response from students. The use of instructional media will greatly help teachers and students in the learning process so that it will have an impact on student interest and motivation. [41] explained that learning media is anything that can transmit messages or information so that it can stimulate students' thoughts, feelings, interests, and attention. [16] explained that learning media is a tool that can help teachers deliver teaching material to students so as to encourage students to pay attention to the material presented. One of the learning media that is able to visualize mathematical theories and concepts is learning videos. Through the provision of problem-oriented mathematics learning videos, students can understand the scale better but while still having fun. This is because the problem-oriented mathematics learning video on this scale material is designed by delivering the material through mission games. Fun learning can make students more motivated to learn mathematics and develop their thinking power. Thus, based on the results of the assessment from individual trials, it can be decided that the problemoriented learning video is valid and feasible to be given to students and used in the learning process, especially in mathematics on scale material for the fifth-grade elementary school students.

The results of this study are supported by findings from pre-existing research, namely the results of research from [42] that showed that problem-based learning videos can improve student learning outcomes in the subject of PJOK in the fifth-grade elementary school students. The results of the study from [2] showed that learning videos using problem solving and wondershareassisted model on statistical material were more effective than conventional model learning. The research results from [43] showed that learning tools with problemposing approaches were effective to be applied in scale learning in the fifth-grade elementary school students. Research results from [44] showed that motion graphic media was effective in the learning process. In addition, 
the results of research from [45] showed that the use of a contextual approach in learning could improve the mathematical representation skills of students with high, medium, and low categories compared to conventional approaches. Research results from [26] showed that contextual teaching and learning approach could better improve students' mathematical critical thinking ability compared to using the traditional teaching and learning.

Therefore, the development of problem-oriented mathematics learning videos on scale material for the fifth-grade elementary school students helps overcome the learning problems, especially training students in solving contextual problems. Based on the assessment of experts and individual trials, the learning video is valid for use in the learning process.

\section{CONCLUSION}

Based on the results of the discussion, the conclusion of this development research is that the design of problem-oriented mathematics learning videos using the ADDIE development model includes the analysis, design, development and evaluation stages. However, the implementation stage could not be carried out. The results from the validity tests of the development of problem-oriented mathematics learning videos showed good scores and qualifications from instructional design experts, instructional media experts, subject content experts. In addition, it also received a very good scores and qualifications from individual trials. Based on the assessment of experts and individual trial subjects, it is known that problem-oriented mathematics learning videos are valid so that they are suitable for use in the learning process to help solve learning problems, especially in online mathematics learning. Suggestions that can be put forward are that the results of this study can be used as a reference for relevant research or can be further developed. In its development, an effectiveness test stage shall be added.

\section{REFERENCES}

[1] I. D. G. P. Widiarta, D. P. Parmiti, I. G. Margunayasa, Inkuiri Terbimbing Berbasis Aktivitas Higher Order Thinking Skills Pada Kelas V Sekolah Dasar, REFLEKSI EDUKATIKA: Jurnal Ilmiah Kependidikan 10(1) (2019) 29-39. DOI: https://doi.org/https://doi.org/10.24176/re.v10i1.36 07

[2] I Suriyani, Pengembangan Video Pembelajaran Menggunakan Model Problem Solving Berbantu Wondershare Pada Materi Statistika di SMP, Jurnal Matematika Dan Pendidikan Matematika, 7(1) (2016) 1-13. DOI: https://doi.org/10.26877/aks.v7i1.1405
[3] N. Dantes, Landasan Kependidikan, Graha Ilmu, 2014.

[4] N. M. Sari, A. S. Pamungkas, T. P. Alamsyah, Pengembangan Lembar Kerja Peserta Didik Matematika Berorientasi Higher Order Thinking Skills di Seksolah Dasar, SJME (Supremum Journal of Mathematics Education) 4(2) (2020) 106-123. DOI: https://doi.org/10.35706/sjme.v4i2.3406

[5] Rosiani, M. Anggo, M. Sudia, Pengaruh Pembelajaran Berbasis Masalah Kontekstual Dengan Pendekatan Metakognisi Terhadap Kemampuan Pemecahan Masalah Matematika Siswa Kelas VIII SMP, Jurnal Pembelajaran Berpikir Matematika 1(1) (2016) 71-82. DOI: https://doi.org/http://dx.doi.org/10.33772/jpbm.v1i 1.5419

[6] G. A. D. Sugiharni, Pengujian Validitas Konten Media Pembelajaran Interaktif Berorientasi Model Creative Problem Solving. Jurnal Penelitian Dan Pengembangan Pendidikan 2(2) (2018) 88. DOI: https://doi.org/10.23887/jppp.v2i2.15378

[7] R. H. Rusiyanti, Pengembangan Perangkat Pembelajaran Matematika Berbasis Konstruktivisme Untuk Melatih Kemampuan berpikir Kritis Siswa SMA Kelas X, Jurnal Pendidikan Matematika 5(2) (2014) 185-204. DOI: https://doi.org/10.22342/jpm.5.2.598.

[8] OECD, Program for International Student Assesment (PISA) Result from Pisa, 2019.

[9] R. Anggraeni, I. Herdiman, Kemampuan Pemecahan Masalah Matematik Siswa SMP Pada Materi Lingkaran Berbentuk Soal Kontekstual Ditinjau dari Gender, Numeracy Journal 5(1) (2018) 19-28. DOI: https://doi.org/https://doi.org/10.46244/numeracy.v $5 \mathrm{i} 1.293$

[10] H. Hartatiana, Pengembangan Soal Pemecahan Masalah Berbasis Argumen Untuk Siswa Kelas V Di Sd Negeri 79 Palembang, Jurnal Pendidikan Matematika vol. 8(2), 2014. DOI: https://doi.org/10.22342/jpm.8.2.1912.76-85

[11] G. Polya, How to Solve It: A New Aspect of Mathematical Method (Second ed), Princeton University Press, 1973.

[12] S. Mashuri, Media Pembelajaran Matematika, Deepublish, 2019.

[13] M. A. Laili, Pengembangan E-komik (Elektronik Komik) pada Materi Perbandingan dan Skala di Kelas V Sekolah Dasar, University of Muhammadiyah Malang, 2019. 
[14] P. U. Suseno, Y. Ismail, S. Ismail, Pengembangan Media Pembelajaran Matematika Video Interaktif berbasis Multimedia, Jambura Journal of Mathematics Education 1(2) (2020) 59-74. DOI: https://doi.org/10.34312/jmathedu.v1i2.7272

[15] A. Pratama, S. Widodo, Pengembangan Media Video Pembelajaran Pada Mata Pelajaran Bahasa Jawa Materi Pokok Aksara Jawa Untuk Siswa Kelas IV di SD Negeri 1 Jemundo, Jurnal Mahasiswa Teknologi Pendidikan 9(1) (2018) 1-9. https://jurnalmahasiswa.unesa.ac.id/index.php/jmtp /article/view/24133

[16] S. N. Ngaini, B. P. Darminto, P. B. B. Darmono, Pengembangan Media Pembelajaran Matematika melalui Lagu dan Video pada Pembelajaran Perbandingan dan Skala untuk Siswa Sekolah Dasar, 2020. http://eproceedings.umpwr.ac.id/index.php/sendika /article/view/1201

[17] A. Lukman, D. K. Hayati, N. Hakim, Pengembangan Video Animasi Berbasis Kearifan Lokal pada Pembelajaran IPA Kelas V di Sekolah Dasar, Elementary: Jurnal Ilmiah Pendidikan Dasar 5(2) (2019) 153-166. DOI: https://doi.org/10.32332/elementary.v5i2.1750

[18] H. H. Batubara, D. N. Ariani, Pemanfaatan Video sebagai Media Pembelajaran Matematika SD/MI, Muallimuna : Jurnal Madrasah Ibtidaiyah 2(1)(016) 47-66. DOI: https://doi.org/10.31602/muallimuna.v2i1.741

[19] V. N. Hikmah, I. Purnamasari, Pengembangan Video Animasi "Bang Dasi" Berbasis Aplikasi Camtasia Pada Materi Bangun Datar Kelas V Sekolah Dasar, Pengembangan Video Animasi "Bang Dasi" Berbasis Aplikasi Camtasia Pada Materi Bangun Datar Kelas V Sekolah Dasar 4(2) (2017) 182-191. DOI: https://doi.org/10.23819/mimbar-sd.v4i2.6352

[20] V. A. Melinda, I. N. S. Degeng, D. Kuswandi, Pengembangan Media Video Pembelajaran IPS Berbasis Virtual Field Trip (VFT) pada Kelas V SDNU Kraton Kencong. Jurnal Inovasi Dan Teknologi Pembelajaran 3(2) (2017) 158-164. DOI: https://doi.org/http://dx.doi.org/10.17977/um031v3 i22017p 158

[21] A. D. S. Krissandi, Pengembangan video tematik sebagai pengantar pembelajaran kurikulum 2013 di sekolah dasar, Premiere Educandum: Jurnal Pendidikan Dasar Dan Pembelajaran 8(1) (2018) 68. DOI: https://doi.org/10.25273/pe.v8i1.2233
[22] T. I. B. Al-tabany, Mendesain Model Pembelajaran Inovatif, Progresif, dan Kontekstual: Konsep, Landasan, dan Implementasinya pada Kurikulum 2013 (Kurikulum Tematik Integratif/KTI), KENCANA, 2017.

[23] U. Uslima, C. Ertikanto, U. Rosidin, Contextual Learning Module Based on Multiple Representations: The Influence on Students' Concept Understanding, Tadris: Jurnal Keguruan Dan Ilmu Tarbiyah 3(1) (2018) 11-20. DOI: https://doi.org/10.24042/tadris.v3i1.2534

[24] E. Ningrum, Pendekatan Kontekstual (Contextual Teaching and Learning), Pelatihan Dan Workshop Model-Model Pembelajaran Dalam Persiapan RSBI, 2009.

[25] V. A. Nurlaily, H. Soegiyanto, B. Usodo, Elementary school teacher's obstacles in the implementation of problem-based learning model in mathematics learning, Journal on Mathematics Education 10(2) (2019) 229-238. DOI: https://doi.org/10.22342/jme.10.2.5386.229-238

[26] Kurniati, Y. S. Kusumah, J. Sabandar, T. Herman, Mathematical Critical Thinking Ability Through Contextual Teaching and Learning Approach, Indonesian Mathematical Society Journal on Mathematics Education 6(1) (2015) 53-62. DOI: https://doi.org/https://doi.org/10.22342/jme.6.1.190 $1.53-62$

[27] M. Rizki, Profil Pemecahan Masalah Kontekstual Matematika Oleh Siswa Kelompok Dasar, Jurnal Dinamika Penelitian: Media Komunikasi Sosial Keagamaan 18(02) (2018) 271-286. DOI: https://doi.org/https://doi.org/10.21274/dinamika.2 018.18.2.271-286

[28] K. J. Loli, N. W. Damayanti, E. Yuniarto, Pengembangan Lks Berdasarkan Masalah Kontekstual Pada Materi Operasi Hitung Bentuk Aljabar, Edu Sains: Jurnal Pendidikan Sains \& Matematika 6(1), (2018) 30-36. DOI: https://doi.org/10.23971/eds.v6i1.897

[29] R. Putri, Lambertus, M. Sudia, Analisis Kesalahan Menyelesaikan Masalah Kontekstual Ditinjau Dari Gender, Jurnal Pembelajaran Berfikir Matematika 5(1) (2020) 65-75. DOI: https://doi.org/http://dx.doi.org/10.33772/jpbm.v5i 1.15744

[30] Marna, Ruswanti, Meningkatkan Pemahaman dan Hasil Belajar Siswa pada Materi Perbandingan dan Skala Melalui Pembelajaran Kontekstual, Journal of Education in Mathematics, Science, and Technology 1(2) (2018) 1-7. 
http://jemst.ftk.uinjambi.ac.id/index.php/jemst/artic le/view/7

[31] Y. Agnesti, R. Amelia, Penerapan Pendekatan Kontekstual dalam Menyelesaikan Soal Cerita pada Materi Perbandingan dan Skala terhadap Siswa SMP, Mosharafa : Jurnal Pendidikan Matematika 9(2) (2020) 347-358. https://doi.org/https://doi.org/10.31980/mosharafa. v9i2.748

[32] A. A. G. Agung, Metodologi Penelitian Pendidikan, Universitas Pendidikan Ganesha, 2014.

[33] Sukardi, Metodologi Penelitian Pendidikan Kompetensi dan Praktiknya, Bumi Aksara, 2018.

[34] D. A. Bujuri, Analisis Perkembangan Kognitif Anak Usia Dasar dan Implikasinya dalam Kegiatan Belajar Mengajar, LITERASI: Jurnal Ilmu Pendidikan 9(1) (2018) 37-50. DOI: https://doi.org/10.21927/literasi.2018.9(1).37-50

[35] S. Wahyuni, Hasdin, Nurvita, Penerapan Metode Kerja Kelompok untuk Meningkatkan Hasil Belajar IPS pada Siswa Kelas III di SDN 15 Biau, Jurnal Kreatif Tadulako Online 5(3) (2017) 1-14. http://jurnal.untad.ac.id/jurnal/index.php/JKTO/arti cle/download/3847/9488

[36] I. M. Tegeh, I. N. Jampel, K. Pudjawan, Buku Ajar Model-Model Pengembangan, Jurusan Teknologi Pendidikan, Fakultas Ilmu Pendidikan, Universitas Pendidikan Ganesha, 2014.

[37] A. C. Prihandoko, Memahami Konsep Matematika Secara Benar dan Menyajikannya dengan Menarik, Depdiknas. 2006.

[38] P. Setyosari, Desain Pembelajaran, Bumi Aksara, 2020

[39] Rusman, Belajar dan Pembelajaran, Prenadamedia group, 2018.

[40] B. A. Pribadi, Media dan Teknologi dalam Pembelajaran. Kencana, 2017.

[41] S. Mashuri, Media Pembelajaran Matematika, DEEPUBLISH, 2019.

[42] L. P. M. K. Dewi, D. P. Parmiti, I N. Jampe, Pengembangan Video Berbasis Masalah Pada Mata Pelajaran Pjok Untuk Meningkatkan Hasil Belajar Siswa Kelas V, E-Journal Edutech Universitas Pendidikan Ganesha, 5(2), 2016. DOI: https://doi.org/http://dx.doi.org/10.23887/jeu.v4i2. 7670

[43] Siyamtini, S. M. Amin, T. Y. E. Siswono, Pengembangan Perangkat Pembelajaran dengan Pendekatan Pengajuan Masalah pada Materi Perbandingan dan Skala di Kelas V SD, Jurnal
Review Pendidikan Dasar: Kajian Pendidikan Dan Hasil Penelitian, vol. 5(1), 2019. DOI: https://doi.org/http://dx.doi.org/10.26740/jrpd.v5n2 .p976-985

[44] T. P. Wardaniasih, S. R. Yuliati, I. Lestari, Model Konseptual Media Motion Graphic Interaktif, Jurnal Parameter 32(1) (2020) 53-74. DOI: https://doi.org/doi.org/10.21009/parameter.321.04

[45] E. Surya, J. Sabandar, Y. S. Kusumah, Darhim, Mathematical Problem Solving by Schoenfeld.pdf, IndoMS. J.M.E, 4(1) (2013) 113-126. DOI: https://doi.org/https://doi.org/10.22342/jme.4.1.568 $.113-126$ 